DOI: https://doi.org/10.24127/ajpm.v9i2.2740

\title{
KESALAHAN REPRESENTASI PECAHAN PADA GARIS BILANGAN
}

\author{
Tatik Retno Murniasih ${ }^{1}$, Cholis Sa'dijah $^{2 *}$, Makbul Muksar $^{3}$, Susiswo $^{4}$, \\ Vivi Suwanti ${ }^{5}$
}

\author{
$1,2^{*}, 3,4$ Universitas Negeri Malang, Malang, Indonesia \\ ${ }^{1,5}$ Universitas Kanjuruhan, Malang, Indonesia \\ *Corresponding author. Jl. Semarang No. 5, Kota Malang, 65145, Jawa Timur, Indonesia \\ E-mail: $\quad$ cholis.sadijah.fmipa@um.ac.id $^{2 *}$
}

Received 04 April 2020; Received in revised form 21 June 2020; Accepted 24 June 2020

\begin{abstract}
Abstrak
Penelitian tentang analisis kesalahan representasi pecahan calon guru matematika penting karena pecahan berguna dalam kehidupan sehari-hari. Tujuan penelitian untuk menyelidiki kesalahan calon guru matematika dalam representasi tugas kepekaan pecahan pada garis bilangan. Tipe kesalahan dan indikator menunjukkan keterampilan representasi pecahan. Penelitian ini menggunakan pendekatan deskriptif kualitatif dengan 19 calon guru matematika sebagai subjek. Wawancara dilakukan pada 5 subjek yang dipilih. Pada wawancara, diminta untuk mendeskripsikan jawaban mereka dalam merepresentasikan tugas kepekaan pecahan pada garis bilangan dan faktor-faktor yang menyebabkan kesalahan. Hasil penelitian menunjukkan dua kesalahan terbesar pada calon guru matematika, yaitu tidak terampil menggunakan estimasi, dan tidak terampil menggunakan benchmark. Temuan lain menunjukkan lebih banyak calon guru matematika yang melakukan kesalahan dalam representasi pecahan negatif daripada pecahan positif pada garis bilangan. Hal ini disebabkan adanya hambatan kognitif calon guru matematika dari pengetahuan sebelumnya dalam domain pecahan positif ketika diterapkan pada domain pecahan negatif. Sehingga lebih banyak calon guru matematika yang melakukan kesalahan dalam representasi pecahan negatif daripada pecahan positif pada garis bilangan. Faktor-faktor penyebab kesalahan representasi dari penugasan kepekaan pecahan pada garis bilangan adalah calon guru menganggap materi pecahan sulit, sulit membayangkan pecahan, mengalami kebingungan dan lupa dengan materi pecahan. Intervensi berbantuan media direkomendasikan untuk mengatasi ketidakmampuan calon guru menggunakan estimasi dan bencmark terutama dalam domain pecahan negatif.
\end{abstract}

Kata kunci: Garis bilangan; kepekaan pecahan; kesalahan representasi.

\begin{abstract}
The study on the analysis of error representations of pre-service teachers is important fraction are useful in everyday life. The purpose of this study was to investigate the errors of pre-service mathematics teachers in the representation of fraction sense tasks on number lines. The error's level and their factors indicate fraction representation skills. The study used a qualitative descriptive approach with 19 preservice mathematics teachers as prospective subjects. Interviews were conducted on 5 selected subjects. At the interview was asked to describe their answer in representing the number line at fraction sense task and factors causing the error. The results of the study show the two biggest errors for pre-service mathematics teachers, namely the unskilled using estimation, and the unskilled using benchmarks. Other findings show that more pre-service mathematics teachers make mistakes in the representation of negative fractions than positive fractions on the number line. This is due to the cognitive obstacles of preservice mathematics teachers from prior knowledge in the positive fraction domain when applied to the negative fraction domain. So that more pre-service mathematics teachers make mistakes in the representation of negative fractions than positive fractions on the number line. Factors causing the misrepresentation of fraction sense assignments on the number line are the pre-service teacher considers fraction material difficult, improperly imagining fractions, experiencing confusion and forgetting fractions. Media-assisted interventions are recommended to overcome the inability of pre-service teachers to use estimates and benchmarks, especially in the negative fraction domain.
\end{abstract}

Keywords: Error representation; fraction sense; number line. 
DOI: https://doi.org/10.24127/ajpm.v9i2.2740

\section{PENDAHULUAN}

Representasi garis bilangan penting guna membangun keterampilan dalam memecahkan masalah pecahan (Wong, 2013; Aliustaoğlu, Tuna, \& Biber, 2018; Kara \& Incikabi, 2018; Mousley \& Kelly, 2017). Penggunaan garis bilangan dapat mengukur keterampilan seseorang dalam operasi penambahan dan pengurangan pecahan (Kara \& Incikabi, 2018). Kesalahpahaman dari representasi garis bilangan menyebabkan seseorang tidak terampil dalam memecahkan masalah pecahan termasuk tidak membagi garis bilangan dengan partisi atau estimasi yang sama, dan tidak menggunakan bencmark (Aliustaoğlu et al., 2018). Representasi pecahan pada garis bilangan harus diajarkan sampai seseorang terampil memecahkan masalah pecahan (Mousley \& Kelly, 2017).

Keterampilan pecahan harus dikuasai karena berguna dalam kehidupan sehari-hari. Orang-orang yang terampil menyelesaikan pecahan akan berhasil melakukan pekerjaan sebagai tukang kayu, apoteker dan mekanik (Tian \& Siegler, 2017). Tukang kayu dapat memperkirakan jumlah kayu yang dibutuhkan dengan membagi kayu menjadi beberapa bagian untuk membangun rumah dan bangunan. Apoteker dapat mencampur obat sesuai dengan dosis yang dibutuhkan untuk pasien. Mekanik dapat memotong besi untuk membuat bingkai menjadi beberapa bagian. Begitu pentingnya keterampilan pecahan dalam kehidupan, penelitian terkait pecahan perlu dilakukan.

Penelitian tentang representasi pecahan pada garis bilangan sebagian besar dilakukan pada siswa (Aliustaoğlu et al., 2018; Rodrigues, Dyson, Hansen, \& Jordan, 2017; Suryowati, 2015).
Siswa mengalami kesulitan ketika menulis representasi pecahan pada baris angka (Deringöl, 2019). Oleh karena itu, kepekaan pecahan pada siswa perlu dibangun dengan menggunakan representasi garis bilangan (Rodrigues et al., 2017). Kesalahpahaman siswa tentang masalah pecahan dapat dilihat melalui representasi garis bilangan (Aliustaoğlu et al., 2018). Secara umum, hasil penelitian menunjukkan kinerja siswa yang buruk ketika menggunakan representasi garis bilangan. Salah satu faktor yang menyebabkan rendahnya kinerja siswa karena pembelajaran guru yang tidak bermakna sehingga siswa tidak dapat menyelesaikan masalah terkait dengan penggunaan representasi garis bilangan (Cortina, Visnovska, \& Zúñiga, 2014). Penting bagi guru untuk menghubungkan pecahan dan mengaitkannya dengan model representasi (Manfreda Kolar, Hodnik Čadež, \& Vula, 2018; Lamberg \& Wiest, 2014).

Berdasarkan penelitian sebelumnya sudah banyak penelitian terkait representasi pecahan pada siswa dan guru namun belum banyak ditemukan penelitian terkait representasi pecahan pada calon guru matematika. Penelitian pada calon guru di berbagai negara selama sepuluh tahun terakhir lebih banyak meneliti tentang strategi penyelesaian kepekaan pecahan, metode kepekaan pecahan, dan kinerja kepekaan pecahan (Sengul \& Gulbagci, 2012; Courtney-Clarke \& Wessels, 2014). Penelitian yang dilakukan di Taiwan menunjukkan bahwa mayoritas calon guru menggunakan metode berbasis aturan daripada metode kepekaan pecahan. Hasil penelitian di Turki menunjukkan calon guru lebih banyak menggunakan strategi berbasis aturan. Hasil penelitian 
pada calon guru di Namibia menunjukkan kinerja yang buruk pada tugas kepekaan pecahan. Selain itu, penelitian tentang calon guru juga lebih banyak meneliti tentang penalaran pecahan dan pembagian pecahan menggunakan representasi luas daerah (Lamberg \& Wiest, 2014; Izsák, Beckmann, \& Bradshaw, 2016).

Ada beberapa indikator untuk menentukan representasi pecahan pada garis bilangan. Bencmark dan estimasi digunakan sebagai indikator untuk membandingkan ukuran dan lokasi pecahan pada garis bilangan (Sa'dijah, 2013; Tsao \& Pan, 2013). Kepekaan terhadap pecahan senilai adalah salah satu indikator keterampilan dalam memecahkan masalah kepekaan pecahan (Tucker, 2014). Menurut Way, indikator dalam memecahkan masalah kepekaan pecahan, antara lain, dapat merepresentasikan pecahan dengan berbagai model (Way, 2011). Beda penelitian ini dibandingkan dengan penelitian sebelumnya yaitu pada penelitian ini akan menganalisis kesalahan representasi berdasarkan gabungan semua indikator dari penelitian sebelumnya yaitu kepekaan terhadap pecahan senilai, benchmark, estimasi, dan representasi pecahan pada garis bilangan. Selain itu penelitian sebelumnya dilakukan pada domain pecahan positif sedangkan pada penelitian ini ditambahkan pada domain pecahan negatif.

Kesalahan calon guru matematika dalam representasi pecahan pada garis bilangan penting untuk diteliti karena keberhasilan guru disebabkan oleh kemampuan calon guru yang baik. Beberapa peneliti mengatakan ada hubungan antara kesalahan dan keterampilan (Tuba, 2017; Son \& Lee, 2016).
Berdasarkan penjelasan di atas, masalah dalam penelitian ini adalah bagaimana kesalahan representasi pecahan calon guru matematika dilihat dari tipe kesalahan dan faktor-faktor yang menyebabkan kesalahan. Penelitian ini bertujuan untuk mengetahui kesalahan calon guru matematika terkait tugas kepekaan pecahan menggunakan garis bilangan serta faktor-faktor yang menyebabkan kesalahan.

\section{METODE PENELITIAN}

Metode yang digunakan dalam penelitian yaitu deskriptif kualitatif. Keterampilan calon guru matematika dalam menulis representasi pecahan pada garis bilangan dianalisis kesalahannya berdasarkan tugas tertulis dan wawancara. Subjek penelitian sebanyak 19 orang calon guru matematika dari salah satu perguruan tinggi swasta di Malang. Mereka diberi 2 tugas kepekaan pecahan dan kemudian hasil pekerjaannya dianalisis serta dikelompokkan berdasarkan tipe kesalahan. Selanjutnya dipilih subjek untuk diwawancara. Pemilihan subjek wawancara berdasarkan indikator kesalahan dan subjek mempunyai kemampuan komunikasi yang baik.

Instrumen yang digunakan antara lain lembar tugas, pedoman wawancara, alat rekam, dan catatan lapangan. Lembar tugas terdiri dari dua pertanyaan. Pertanyaan pertemuan 1 (P1) pada lembar tugas digunakan untuk mengukur kesalahan representasi pecahan positif. Sedangkan pertanyaan pertemuan 2 (P2) untuk mengukur kesalahan representasi pecahan negatif. Menurut Murniasih, Sa'dijah, Muksar, \& Susiswo, (2018), lembar tugas dapat digunakan untuk mengetahui kesalahan representasi pecahan. Berdasarkan lembar tugas maka subjek 
yang menjawab salah dikelompokkan berdasarkan jenis kesalahan dan diwawancara subjek yang terpilih. Kegiatan wawancara mengacu pada pedoman wawancara yang sudah divalidasi oleh validator. Alat rekam digunakan untuk mengambil gambar subjek dan merekam proses pengerjaan tugas serta wawancara. Catatan lapangan digunakan peneliti untuk mencatat calon guru mengerjakan tugas dan menjawab pertanyaan wawancara.

Tabel 1. Jenis kesalahan dan indikator keterampilan.

\begin{tabular}{|c|c|c|c|}
\hline \multicolumn{3}{|c|}{ Jenis Kesalahan } & Indikator Keterampilan \\
\hline $\begin{array}{l}\text { Kesalahan } \\
\text { (E1) }\end{array}$ & Tipe & 1 & $\begin{array}{l}\text { Keterampilan dalam membuat representasi pecahan positif } \\
\text { pada garis bilangan }\end{array}$ \\
\hline $\begin{array}{l}\text { Kesalahan } \\
\text { (E2) }\end{array}$ & Tipe & 2 & $\begin{array}{l}\text { Keterampilan dalam membuat representasi pecahan negatif } \\
\text { pada garis bilangan }\end{array}$ \\
\hline $\begin{array}{l}\text { Kesalahan } \\
\text { (E3) }\end{array}$ & Tipe & 3 & $\begin{array}{l}\text { Keterampilan dalam menggunakan estimasi jarak pada garis } \\
\text { bilangan }\end{array}$ \\
\hline $\begin{array}{l}\text { Kesalahan } \\
\text { (E4) }\end{array}$ & Tipe & 4 & $\begin{array}{l}\text { Keterampilan dalam menggunakan bencmark pada garis } \\
\text { bilangan }\end{array}$ \\
\hline $\begin{array}{l}\text { Kesalahan } \\
\text { (E5) }\end{array}$ & Tipe & 5 & Keterampilan dalam menentukan pecahan senilai \\
\hline $\begin{array}{l}\text { Kesalahan } \\
\text { (E6) }\end{array}$ & Tipe & 6 & $\begin{array}{l}\text { Keterampilan dalam membuat representasi pecahan dari } \\
\text { simbol pecahan ke garis bilangan }\end{array}$ \\
\hline
\end{tabular}

Tabel 2. Tugas pertemuan 1-2 dan jenis kesalahan.

\begin{tabular}{|c|c|c|c|c|c|}
\hline Pertemuan & \multicolumn{4}{|c|}{ Tugas } & \multirow{4}{*}{\begin{tabular}{l}
\multicolumn{1}{c}{$\begin{array}{c}\text { Jenis } \\
\text { Kesalahan }\end{array}$} \\
E1, E3, E4, E5 \\
E6
\end{tabular}} \\
\hline \multirow[t]{3}{*}{$\mathrm{P} 1$} & \multicolumn{4}{|c|}{$\begin{array}{l}\text { Tunjukkan lokasi setiap pecahan positif di bawah } \\
\text { pada garis bilangan! }\end{array}$} & \\
\hline & 1 & 2 & 2 & & \\
\hline & $\overline{3}, \quad \overline{4}$ & $\overline{6}$ & & & \\
\hline \multirow[t]{3}{*}{$\mathrm{P} 2$} & \multicolumn{4}{|c|}{$\begin{array}{l}\text { Tunjukkan lokasi setiap pecahan negatif di bawah } \\
\text { pada garis bilangan! }\end{array}$} & $\begin{array}{l}\text { E2, E3, E4, E5, } \\
\text { E6 }\end{array}$ \\
\hline & $\begin{array}{lll}1 & 1\end{array}$ & 2 & 3 & 7 & \\
\hline & $-\frac{-}{3}$ & $\overline{8}$ & $-\frac{-}{6}$ & $-\overline{8}$ & \\
\hline
\end{tabular}

Dalam penelitian ini dibatasi pada representasi pecahan dengan model garis bilangan. Indikator untuk menentukan representasi pada garis bilangan terkait masalah kepekaan pecahan diadaptasi dari beberapa ahli. Dari berbagai teori yang mendukung, peneliti mengadaptasi dan menggabungkan indikator keterampilan pecahan dari penelitian sebelumnya, yaitu penggunaan estimasi, bencmark, kepekaan pecahan senilai, dan representasi pecahan dengan model garis bilangan (Tsao \& Pan, 2013; Sa'dijah, 2013; Tucker, 2014; Way, 2011).

Indikator kesalahan calon guru ketika menulis representasi pecahan pada garis bilangan dapat dilihat pada Tabel 1 (diadaptasi dari Tsao \& Pan, 
2013; Tucker, 2014; Way, 2011; Sa'dijah, 2013). Sedangkan tugas kepekaan pecahan dan jenis kesalahan dapat dilihat pada Tabel 2, pertanyaan diadaptasi dari (Shumway, 2011). Analisis data menggunakan tahapan Milles \& Huberman, yang terdiri dari mentranskrip data, mengamati data, mereduksi data, mengkategorikan data, memvalidasi data, menginterpretasikan data, dan menarik kesimpulan (Miles, Huberman \& Saldana, 2014)

\section{HASIL DAN PEMBAHASAN}

Tugas kepekaan pecahan selama 2 pertemuan dapat dilihat pada Tabel 2. Berdasarkan hasil pekerjaan tugas pertemuan $1(\mathrm{P} 1)$ dan $2(\mathrm{P} 2)$ dianalisis kesalahannya dan dikelompokkan berdasarkan jenis kesalahannya.
Selanjutnya dipilih 5 dari 19 calon guru matematika sebagai subjek wawancara, yaitu subjek 1 (S1), subjek 2 (S2), subjek 3 (S3), subjek 4 (S4), dan subjek 5 (S5). Pemilihan subjek wawancara berdasarkan jenis kesalahan dan selanjutnya dipilih subjek yang memiliki komunikasi bagus. Berikut ini adalah penjelasan tentang subjek yang masih menemui kesalahan representasi pecahan.

Kegiatan pada P1 memberikan tugas pecahan positif yang harus ditempatkan pada garis bilangan. Menuliskan lokasi pecahan positif dengan benar pada garis bilangan adalah fokus dari P1. Subjek terpilih yang memiliki kesalahan pada tugas P1 yaitu S1, S2, dan S3.

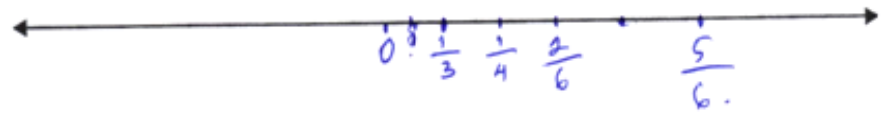

Gambar 1. Jawaban S1 pada P1.

Pada Gambar 1, S1 memiliki kesalahan E1, E3, E4, E5, dan E6. S1 salah merepresentasikan pecahan positif dari representasi simbol ke representasi garis bilangan (E1, dan E6). S1 tidak terampil menggunakan estimasi (E3) ketika menempatkan pecahan pada garis bilangan. S1 hanya menulis angka 0 dan tidak menuliskan angka 1 sebagai bencmark (E4). Selain itu, S1 juga keliru menuliskan pecahan senilai yaitu $\frac{1}{3}$ dan $\frac{2}{6}$ (E5). Untuk mengungkap kesalahan secara mendalam, peneliti melakukan wawancara klinis dengan $\mathrm{S} 1$. Berdasarkan hasil wawancara, S1 menceritakan bahwa pertama S1 mempertimbangkan penyebut yaitu semakin besar penyebut maka nilai pecahan semakin besar. S1 juga mengatakan jika ada dua pecahan yang memiliki penyebut yang sama maka pecahan yang pembilangnya lebih besar mempunyai nilai lebih besar. S1 mengatakan lupa kalau $\frac{2}{6}$ dapat disederhanakan menjadi $\frac{1}{3}$ dan mengatakan pecahan merupakan materi yang sulit.

Subjek terpilih lain yang memiliki kesalahan pada tugas P1 yaitu S2. Subjek 2 memiliki kesalahan E3, dan E4 (Gambar 2). S2 benar menempatkan pecahan positif pada garis bilangan namun S2 tidak dapat menggunakan estimasi jarak yang tepat (E3) ketika menulis pecahan positif. Selain itu, S2 tidak menulis 0 dan 1 sebagai bencmark (E4). 
DOI: https://doi.org/10.24127/ajpm.v9i2.2740

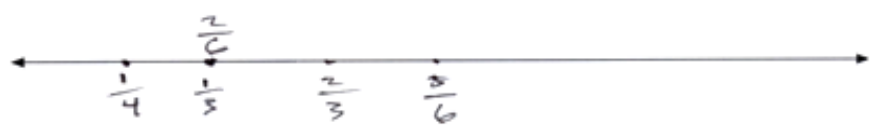

Gambar 2. Jawaban S2 pada P1.

Hasil wawancara dengan S2 menunjukkan penyebab kesalahan, yaitu bahwa S2 menganggap pecahan sebagai materi yang sulit karena pecahan jarang ditemui dalam kehidupan sehari-hari.

Pada Gambar 3, S3 memiliki kesalahan E1, E3, E5, dan E6 pada tugas P1. S3 salah merepresentasikan $\frac{1}{3}$ dan $\frac{2}{6}$ (E5). S3 sudah menggunakan angka 0, 1 sebagai bencmark, tetapi S3 tidak akurat memperkirakan jarak dalam penempatan pecahan positif (E3). Kesalahan S3 menyebabkan subjek menjadi tidak terampil untuk merepresentasikan pecahan positif dari representasi simbol ke representasi garis bilangan (E1 dan E6).

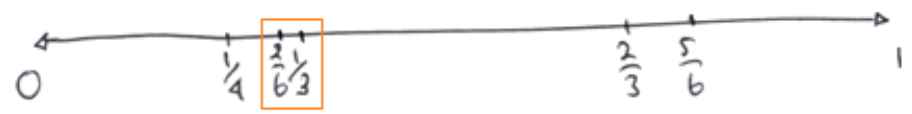

Gambar 3. Jawaban S3 pada P1.

\begin{abstract}
Kesimpulan berdasarkan wawancara bahwa S3 kesulitan membayangkan lokasi pecahan pada garis bilangan dan bingung dengan pecahan.
\end{abstract}

Aktivitas pada pertemuan 2 (P2) memberikan tugas pecahan negatif. Berikut ini adalah perwakilan subjek yang masih memiliki kesalahan dalam menulis representasi pecahan pada tugas P2, yaitu S4 dan S5.

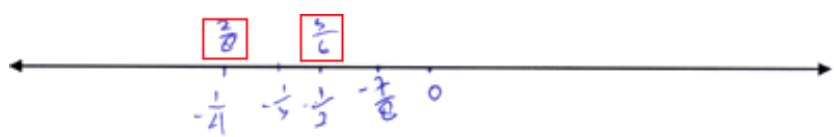

Gambar 4. Jawaban S4 pada P2.

S4 pada Gambar 4, memiliki tipe kesalahan E2, E3, E4, E5, dan E6. S4 menganggap bahwa semakin jauh ke kiri pecahan semakin besar. S4 mengabaikan tanda negatif. Meskipun S4 benar menempatkan pecahan senilai, namun S4 masih salah menuliskan representasi simbol (E2 dan E6) karena tidak menuliskan tanda negatif pada pecahan $\frac{3}{6}$ (E5) dan menggunakan estimasi jarak yang masih salah (E3). Selain itu, S4 juga tidak menggunakan angka -1 sebagai bencmark (E4) pada garis bilangan.

Pada Gambar 5, S5 memiliki tipe kesalahan E2, E3, E4, E5, dan E6. S5 tidak menggunakan angka 1 sebagai bencmark (E4). Selain itu, S5 juga tidak mempertimbangkan estimasi jarak (E3) dan tidak memiliki kepekaan terhadap pecahan senilai (E5). Hasil wawancara terhadap S5 mengatakan kesulitan dengan pecahan negatif.

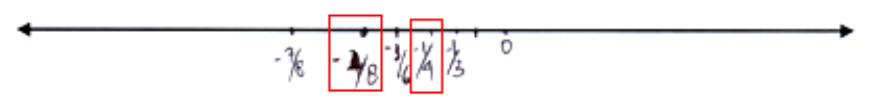

Gambar 5. Jawaban S5 pada P2. 
DOI: https://doi.org/10.24127/ajpm.v9i2.2740

Secara umum, kesalahan calon guru matematika dalam menulis pecahan pada garis bilangan dapat dilihat pada Tabel 3.

Tabel 3. Lima subjek yang melakukan kesalahan.

\begin{tabular}{cll}
\hline \multirow{2}{*}{ Subjek } & \multicolumn{2}{c}{ Tipe Kesalahan } \\
\cline { 2 - 3 } & \multicolumn{1}{c}{ P1 } & \multicolumn{1}{c}{ P2 } \\
\hline S1 & E1, E3, E4, E5, E6 & E2, E3, E4, E5, E6 \\
S2 & E3, E4 & E2, E3, E4, E5, E6 \\
S3 & E1, E3, E5, E6 & E2, E3, E4, E5, E6 \\
S4 & E3, E4 & E2, E3, E4, E5, E6 \\
S5 & - & E2, E3, E4, E5, E6 \\
\hline
\end{tabular}

Berdasarkan Tabel 3. jenis kesalahan terbesar terjadi dalam menggunakan estimasi (E3), dan bencmark (E4). Kesalahan dalam menggunakan estimasi jarak (E3) menyebabkan calon guru tidak mampu membandingkan pecahan yang lebih besar atau lebih kecil pada garis bilangan. Hasil ini sejalan dengan penelitian Kor, Teoh, Binti Mohamed, \& Singh, (2018) yang mengatakan seseorang yang tidak memiliki kepekaan pecahan tidak dapat membuat estimasi pecahan dengan baik. Padahal salah satu keterampilan matematika yang harus dikuasai adalah mampu memperkirakan jawaban dan solusi secara akurat (Shodikin, 2017). Calon guru juga tidak menggunakan angka 0 , 1, atau -1 sebagai bencmark ketika menempatkan pecahan pada garis angka (E4). Hasil ini sejalan dengan penelitian Sengul \& Gulbagci, (2012) yang mengatakan hanya sebagian kecil calon guru menggunakan bencmark sebagai titik referensi. Selain itu, keterampilan calon guru masih rendah dalam menulis representasi pecahan senilai. Calon guru tidak dapat menempatkan pecahan senilai pada posisi yang sama pada garis bilangan (E5). Berdasarkan wawancara, diketahui bahwa calon guru tidak dapat membayangkan lokasi pecahan pada garis bilangan dan memiliki kebingungan tentang pecahan negatif.
Calon guru mengalami hambatan kognitif ketika mengerjakan pecahan negatif.

Hambatan kognitif terjadi ketika
calon guru menggeneralisasi pengetahuan sebelumnya dalam domain positif dan kemudian diterapkan pada domain negatif. Representasi pecahan positif pada garis bilangan di sebelah kanan nol semakin ke kanan semakin besar nilai pecahannya, menjadi kontradiksi ketika diterapkan pada pecahan negatif di sebelah kiri nol semakin ke kiri semakin kecil nilai pecahannya. Hal ini dapat dilihat dari hasil pekerjaan S4 (Gambar 4) yang menulis pecahan negatif di sebelah kiri nol pada garis bilangan, semakin ke kiri semakin besar nilai pecahannya. Sementara penelitian sebelumnya hanya mengungkapkan ketidakmampuan calon guru dalam memecahkan pecahan positif (Sengul \& Gulbagci, 2012; Yaman, 2015). Calon guru belum terampil merepresentasikan pecahan negatif pada garis bilangan daripada pecahan positif. Temuan penelitian menunjukkan calon guru matematika lebih banyak membuat kesalahan ketika merepresentasikan pecahan negatif (E2) dibandingkan dengan pecahan positif. Berdasarkan hasil wawancara, diketahui bahwa calon guru menganggap pecahan sulit dan telah lupa dengan pecahan negatif. Hasil ini sejalan dengan 
DOI: https://doi.org/10.24127/ajpm.v9i2.2740

penelitian sebelumnya yang mengatakan pecahan menyebabkan kesulitan untuk anak-anak dan orang dewasa (Lortie-Forgues, Tian, \& Siegler, 2015; Sutiarso, 2019). Kesalahan calon guru yang telah lupa dengan pecahan negatif disebabkan oleh pembelajaran yang tidak bermakna (Prediger, 2008).

Calon guru juga memiliki kesalahan ketika merepresentasikan pecahan dari simbol ke model garis bilangan (E6). Hal ini sejalan dengan hasil penelitian yang mengatakan keterampilan representasi pecahan calon guru masih rendah (Boyce \& Moss, 2017). Oleh karena itu meningkatkan kepekaan pecahan pada calon guru matematika adalah hal yang penting untuk dilakukan (Whitacre \& Nickerson, 2016).

\section{KESIMPULAN DAN SARAN}

Kesalahan terbesar dalam representasi penugasan kepekaan pecahan pada calon guru matematika antara lain tidak terampil menggunakan estimasi, dan benchmark. Selain itu, calon guru matematika belum terampil menulis representasi pecahan negatif dibandingkan dengan pecahan positif pada garis bilangan, hal ini disebabkan calon guru mengalami hambatan kognitif. Berdasarkan hasil wawancara menunjukkan bahwa calon guru menganggap pecahan sulit dan sudah lupa dengan konsep pecahan yang telah dipelajari. Calon guru tidak dapat membayangkan letak pecahan pada garis bilangan dan mengalami kebingungan ketika menempatkan pecahan negatif pada garis bilangan. Calon guru mengalami hambatan kognitif ketika menuliskan representasi pecahan negatif.

Penelitian selanjutnya direkomendasikan untuk memberikan intervensi kepada calon guru yang belum terampil merepresentasikan tugas kepekaan pecahan pada garis bilangan dengan media kertas milimeter block maupun media berbantuan komputer. Kedua media tersebut disarankan guna membantu mengatasi kesulitan calon guru matematika dalam penggunaan estimasi, dan bencmark.

\section{DAFTAR PUSTAKA}

Aliustaoğlu, F., Tuna, A., \& Biber, A. Ç. (2018). Misconceptions of sixth grade secondary school students on fractions. International Electronic Journal of Elementary Education, 10(5), 591-599.

Boyce, S., \& Moss, D. (2017). Role of representation in prospective teachers' fraction schemes. In E. Galindo \& J. Newton (Eds.), Proceedings of the 39th annual meeting of the North American Chapter of the International Group for the Psychology of Mathematics Education. (pp. 829-836). Indianapolis, IN: Hoosier Association of Mathematics Teacher Educators.

Cortina, J. L., Visnovska, J., \& Zúñiga, C. (2014). Equipartition as a didactical obstacle in fraction instruction. Acta Didactica Universitatis Comenianae Mathematics, (14), 1-18.

Courtney-Clarke, M., \& Wessels, H. (2014). Number sense of final year pre-service primary school teachers. Pythagoras, 35(1), 1-9.

Deringöl, Y. (2019). Misconceptions of primary school students about the subject of fractions: Views of primary teachers and primary preservice teachers. International Journal of Evaluation and Research in Education (IJERE), 8(1), 29-38. 
Izsák, A., Beckmann, S., \& Bradshaw, L. (2016). Preservice teacher education. Proceedings of the 38th Annual Meeting of the North American Chapter of the International Group for the Psychology of Mathematics Education. Tucson, AZ: The University of Arizona.

Kara, F., \& Incikabi, L. (2018). Sixth grade students' skills of using multiple representations in addition and subtraction operations in fractions. International Electronic Journal of Elementary Education, 10(4), 463-474.

Kor, L.-K., Teoh, S.-H., Binti Mohamed, S. S. E., \& Singh, P. (2018). Learning to make sense of fractions: Some insights from the Malaysian primary 4 pupils. International Electronic Journal of Mathematics Education, 14(1), 169-182.

Lamberg, T., \& Wiest, L. R. (2014). Dividing fractions using an area model: A look at in-service teachers' understanding. Mathematics Teacher Education and Development, 17(1), 30-43.

Lortie-Forgues, H., Tian, J., \& Siegler, R. S. (2015). Why is learning fraction and decimal arithmetic so difficult? Developmental Review, 38(1), 201-221.

Manfreda Kolar, V., Hodnik Čadež, T., \& Vula, E. (2018). Primary teacher students' understanding of fraction representational knowledge in Slovenia and Kosovo. Center for Educational Policy Studies Journal, 8(2), 71-96.

Miles, M.B., Huberman, A.M., and Saldara, J. (2014). Qualitative data analysis, a methods sourcebook. USA: Sage Publication.
Mousley, K., \& Kelly, R. R. (2017). Developing deaf students fraction skills requires understanding magnitude and whole number division. Journal of Education and Learning, 7(2), 12-20.

Murniasih, T. R., Sa'dijah, C., Muksar, M., \& Susiswo, S. (2018). Errors in representation translation in solving problems related to number sense of pre-service math teachers. In A. G. Abdullah, R. Rusfandi, U. Jawas, \& A. B. D. Nandiyanto (Eds.), Proceedings of the Annual Conference on Social Sciences and Humanities (ANCOSH) (pp. 393399). SCITEPRESS - Science and Technology Publications, Lda. A.

Prediger, S. (2008). The relevance of didactic categories for analysing obstacles in conceptual change: revisiting the case of multiplication of fractions. Learning and Instruction, 18(1), 3-17.

Rodrigues, J., Dyson, N. I., Hansen, N., \& Jordan, N. C. (2017). Preparing for algebra by building fraction sense. Teaching Exceptional Children, 49(2), 134-141.

Sa'dijah, C. (2013). Kepekaan bilangan siswa SMP melalui pembelajaran matematika kontekstual dan mengintegrasikan ketrampilan berpikir kreatif. Jurnal Pendidikan Dan Pembelajaran, 20(2), 222227.

Sengul, S., \& Gulbagci, H. (2012). An investigation of 5 th grade Turkish students' performance in number sense on the topic of decimal numbers. Procedia - Social and Behavioral Sciences, 46, 22892293.

Shodikin, A. (2017). Effect of learning with abductive-deductive strategy towards the achievement of reasoning ability of high school 
DOI: https://doi.org/10.24127/ajpm.v9i2.2740

students. Infinity Journal, 6(2), 111-120.

Shumway, J. (2011). Number sense routines: building numerical literacy every day in grades $K-3$. Stenhouse Publishing.

Son, J.-W., \& Lee, J.-E. (2016). Preservice teachers' understanding of fraction multiplication, representational knowledge, and computational skills. Mathematics Teacher Education and Development, 18(2), 5-28.

Suryowati, E. (2015). Kesalahan Siswa Sekolah Dasar Dalam Merepresentasikan Pecahan Pada Garis Bilangan. AKSIOMA Journal of Mathematics Education, 4(1), $38-52$.

Sutiarso, S. (2019). Mengapa Sulit Menyelesaikan Soal Pecahan 2/x + $3 / \mathrm{y}=2 / 3$ ? AKSIOMA Journal of Mathematics Education, 8(3), 420428.

Tian, J., \& Siegler, R. S. (2017). Fractions Learning in Children With Mathematics Difficulties. Journal of Learning Disabilities, 50(6), 614-620.

Tsao, Y.-L., \& Pan, T.-R. (2013). The Computational Estimation and Instructional Perspectives of Elementary School Teachers. Journal of Instructional Pedagogies, 11(1), 1-15.

Tuba, A. İ. (2017). The problems posed and models employed by primary school teachers in subtraction with fractions. Educational Research and Reviews, 12(5), 239-250.

Tucker, S. I. (2014). REFractions. APCM, 19(1), 29-34.

Way, J. (2011). Developing Fraction Sense Using Digital Learning Objects. The Australian Association of Mathematics Teachers Inc.
Whitacre, I., \& Nickerson, S. D. (2016). Investigating the Improvement of Prospective Elementary Teachers' Number Sense in Reasoning about Fraction Magnitude. Journal of Mathematics Teacher Education, 19(1), 57-77.

Wong, M. (2013). Locating fractions on a number line. Australian Primary Mathematics Classroom, 2(3), 2227.

Yaman, H. (2015). The Mathematics Education I and II Courses' Effect on Teacher Candidates' Development of Number Sense. Educational Sciences: Theory \& Practice, 15(4), 1119-1135. 